\title{
EFEK PEMBERIAN KONSENTRAT DENGAN PAKAN SAYURAN (DAUN SINGKONG (Manihot utilissima) DAN KOL (Brassica oleraceae L) TERHADAP DAYA TETAS JANGKRIK KALUNG (Gryllus bimaculatus)
}

\author{
The Effect of Feeding Concentrate with Cassava Leaves (Manihot esculenta) and Cabbage \\ (Brassica oleraceae L) on Hatchability Gryllus Bimaculatus
}

\author{
Juni Evalinda Hsb ${ }^{1}$ Tri Hesti Wahyuni $^{2)}$ danSayed Umar ${ }^{2}$
}

${ }^{1}$ Mahasiswa Program Studi Peternakan Fakultas Pertanian Universitas Sumatera Utara,
${ }^{2}$ Staf Pengajar Program Studi Peternakan Fakultas Pertanian Universitas Sumatera Utara

\begin{abstract}
One of the potential resource of animal in Indonesia is Gryllus bimaculatus. The objective of this research is to find out the effect of feeding concentrate with cassava leaves and cabbage on Gryllus bimaculatus. This research was conducted at the Medan Tuntungan, from Mei to July 2015. The research used completely randomize design (CRD) with 4 treatments and 5 replications. Each replications consists of 12 weaning Gryllus bimacullatus. The treatment consists of $P O=$ concentrate, $P 1=$ concentrate cassava leaves, $P 2=$ concentrate + cabbage, $P 3=$ concentrate + cassava leaves + cabbage.The result indicated that the treatment significantly different effect hatching lenght time, egg production and hatchability, while had no significant effect on parent mortalitiy, hatching lenght time (day) on treatment were 10,20;10,80;8,20 and 9,20, respectively, egg production (egg/day) were 170,28; 424,32; 286,64 and 438,24,respectively, hatchability (\%) were 42,6; 34,8; 21 and44,8, respectively, mortality(\%)were 16,$66 ; 14,99 ; 14,98$ and 9,99, respectively. Treatment $P 3$ showed higher egg production and hatching than PO and P1. The conclusion of this research that feeding concentrate with cassava leaves and cabbage improve hatchability, egg production and reduce parent mortality and accelerate hatching lenght time on crickets (Gryllus bimaculatus).
\end{abstract}

Keywords: Cassavaleaves, cabbage,concentrate, hatchability, Gryllus bimaculats.

\begin{abstract}
ABSTRAK
Salah satu potensi sumber daya Indonesia adalah aneka jenis satwa harapan yaitu jangkrik. Penelitian bertujuan untuk mengetahui efek pemberian konsentrat dengan pakan sayuran daun singkong (Manihot utilissima) dan kol (Brassica oleraceae L) terhadap daya tetas jangkrik kalung (Gryllus bimaculatus). Penelitian ini dilakukan Medan Tuntungan, bulan Mei - Juli 2015. Rancangan yang digunakan dalam penelitian ini adalah rancangan acak lengkap (RAL) dengan 4 perlakuan dan 5 ulangan. Setiap ulangan terdiri dari 12 jangkrik kalung. Perlakuan terdiri atas $\mathrm{P} 0=$ konsentrat, $\mathrm{P} 1=$ konsentrat + daun singkong, $\mathrm{P} 2=$ konsentrat + kol dan $\mathrm{P} 3=$ konsentrat + daun singkong + kol.Hasil penelitian menunjukan bahwa perlakuan signifikan terhadap lama penetasan, produksi telur dan daya tetas, sedangkan, mortalitas induk tidak signifikan. Lama penetasan (hari) berturut-turut yaitu 10,$20 ; 10,80 ; 8,20$ dan 9,2, produksi telur (butir/hari) yaitu 170,28; 424,32; 286,64 dan 438,24 , daya tetas(\%) yaitu 42,6; 34,8; 21 dan 44,8 dan mortalitas induk (\%) yaitu 16,66; 14,99; 14,98 dan 9,99. Pada perlakuan $\mathrm{P} 3=$ konsentrat + daun singkong + kol menunjukkan pengaruh pakan dengan pakan sayuran, daun singkong dan kol terhadap daya tetas lebih baik dari pada perlakuan P0, P1 dan P2.Kesimpulan dari hasil penelitian ini menyatakan bahwa pemberian konsentrat dengan daun singkong (Manihot utilissima) dan kol (Brassica oleraceae $L$ ) dapat meningkatkan daya tetas, produksi telur dan mempercepat waktu penetasan pada jangkrik kalung.
\end{abstract}

Kata kunci: Daun singkong, daun kol, konsentrat, daya tetas, jangkrik kalung 


\section{PENDAHULUAN}

Perkembangan budidaya jangkrik di berbagai wilayah di Indonesia dewasa ini skalanya cukup besar, begitu juga dengan seminar-seminar tentang budidaya jangkrik yang banyak diadakan di berbagai kota. Budidaya jangkrik banyak dilakukan mengingat waktu yang dibutuhkan untuk produksi telur yang akan diperdagangkan hanya memerlukan waktu $\pm 2-4$ minggu, sedangkan untuk produksi jangkrik untuk pakan ikan dan burung maupun untuk diambil tepungnya, hanya memerlukan 2- 3 bulan. Dalam siklus hidupnya jangkrik betina mampu memproduksi lebih dari 500 butir telur jangkrik kalung memiliki siklus hidup sampai 75-78 hari (Widiyaningrum, 2001).

Seperti yang diketahui pada awal 1999 sektor pertanian telah diramaikan denganmunculnya ternak jangkrik. Ternyata komoditas jangkrik dapat memberikan tambahanpenghasilan disamping dapat juga dijadikan penghasilan utama. Ada beberapa manfaat dariternak jangkrik yaitu untuk peningkatan kualitas suara burung berkicau dan menambah keindahan warna tubuh ikan awana, selain itu ternyata jangkrik pun digunakan sebagaisalah satu bahan kosmetika setelah mengalami suatu proses.Apalagi akhir - akhir ini di kota-kota besar jangkrik sudah mulai dikonsumsi oleh orang. Banyakmakanan olahan yang berasal dari jangkrik, seperti rempeyek jangkrik, empek - empek jangkrik, siomay jangkrik, sup jangkrik dan lain sebagainya.

Jangkrik tergolong hewan pemakan tumbuhan (herbivora) dan umumnya memakan dedaunan, sayuran dan buah-buahan yang mengandung banyak air. Hal ini disebabkan jangkrik tidak minum air seperti kebanyakan hewan. Makanan tersebut antara lain krokot, sawi, kol, bayam, daun singkong, wortel, gambas dan daun muda. Jangkrik lebih menyukai bagian tanaman yang muda seperti daun dan pucuk tanaman (Paimin et al., 1999).

Makanan jangkrik berupa daun - daunan atau sayur - sayuran seperti : sawi hijau, sawi putih, krokot, bayam dan lain - lain. Memberi jenis pakan sayuran, jangan diberikan secara langsung (dalam kondisi basah), melainkan diangin - anginkan sehingga menjadi setengah layu agar jangkrik tidak pilek dan diare (Soenanto, 1999).

Pemberian pakan buatan (konsentrat) biasanya diberikan untuk jangkrik yang diternakkan terutama pada masa pembesaran yakni 10 hari setelah telur menetas(Sridadi dan Rachmanto, 1999). Tujuan pemberian konsentrat adalah untuk mempercepat pertumbuhan, gerakan menjadi lincah, nimfa menjadi tidak lunak, serta tidak mudah mati, bahwa jangkrik 
yang diberi pakan buatan dengan kadar protein 20\%-22\% lebih baik produksinya dari pada jangkrik yang diberi pakan dengan kadar protein 16\%-18\% (Lumowo ,2001).

Jangkrik kalung memiliki siklus hidup pendek,daya tetas telur tinggi, pertumbuhan cepat dan konversi pakan rendah,serta memiliki kulit tubuh lebih lunak sehingga lebih disukai burung dan satwa pemakan serangga lainnya. Pembawaan dari spesies jangkrik ini tenang, tidak nervous, kerikannya nyaring, lebih agresif dari spesies lainnya dan suka berkelahi sehingga dikenal sebagai jangkrik aduan (Widiyaningrum, 2001).

Jangkrik dapat ditemui di hampir seluruh Indonesia dan hidup dengan baik pada daerah yang bersuhu antara $20-32^{\circ} \mathrm{C}$ dan kelembaban sekitar 65-80\%, bertanah gembur/berpasir. Jangkrikhidup bergerombol dan bersembunyi dalam lipatan-lipatan daun kering atau bongkahan tanah (Sukarno, 1999)

\title{
BAHAN DAN METODE PENELITIAN
}

\section{Tempat dan Waktu Penelitian}

Penelitian ini dilaksanakan di Perumahan de' Gardenia, No.B19, Jln. Bunga Encole, Medan Tuntungan, Sumatera Utara dimulai bulan Mei sampai dengan bulan Juli 2015.

\section{Bahan dan Alat Penelitian}

\section{Bahan}

Bahan yang digunakan yaitu ternak jangkrik kalung umur 10 hari. Pakan buatan yang terdiri dari tepung jagung, tepung ikan, dedak halus dan bungkil kedelai. Daun singkong dan kol sebagai hijauan dalam bentuk segar dan diberikan secara ad libitum. Kandungan nutrisi ransum tertera pada Tabel 1 .

\begin{abstract}
Alat
Alat yang digunakan yaitu kandang indukan 20 unit dengan ukuran $30 \times 25 \times 30 \mathrm{~cm}^{3}$, setiap kandang indukan dilengkapi satu media betelur dan tempat pakan. Media bertelur dengan ukuran $10 \times 6 \times 2 \mathrm{~cm}^{3}$ dengan ketebalan pasir $1,5 \mathrm{~cm}$. Timbangan elektrik berfungsi sebagai alat untuk menimbang bobot hidup jangkrik, termometer untuk mengukur suhu kandang, alat pencatatan data seperti buku data, alat tulis dan kalkulator.
\end{abstract}


Tabel 1. Komposisi Pakan Buatan

\begin{tabular}{llllll}
\hline Bahan & $\begin{array}{l}\text { Bahan } \\
\text { pakan (\%) }\end{array}$ & EM (\%) & PK (\%) & SK (\%) & LK (\%) \\
\hline Tepung Jagung & 48,1 & 1620,97 & 4,1366 & 0,962 & 1,8759 \\
Dedak padi & 20 & 326 & 2,6 & 2,6 & 2,6 \\
Tepung Ikan & 10 & 256,5 & 5,5 & 0,2 & 0,649 \\
Bungkil Kedelai & 21,9 & 501,51 & 8,7819 & 0,94608 & 1,649 \\
\hline Total & 100 & 796,98 & 21 & 4,708 & 6,6 \\
\hline Kol & 50 & - & 1,71 & 0,92 & 0,21 \\
Daun singkong & 50 & - & 22,71 & 9,62 & 3,69 \\
\hline
\end{tabular}

Keterangan : Laboratorium Ilmu Nutrisi dan Pakan Ternak Program Studi Peternakan Fakultas Pertanian. USU (2015)

Tabel2.Formulasi ransum penelitian

\begin{tabular}{lllll}
\hline Bahan & P0 & P1 & P2 & P3 \\
\hline Tepung Jagung & 48,10 & 24,05 & 24,05 & 24,05 \\
Dedak padi & 20,00 & 10,00 & 10,00 & 10,00 \\
Tepung Ikan & 10,00 & 5,00 & 5,00 & 5,00 \\
Bungkil Kedelai & 21,90 & 10,95 & 10,95 & 10,95 \\
Kol (\%) & - & - & 50 & 25 \\
Daunsingkong(\%) & - & 50 & - & 25 \\
\hline Total & 100 & 100 & 100 & 100 \\
\hline PK $(\%)$ & 21,01 & 21,86 & 11,36 & 16,65 \\
LK $(\%)$ & 6,21 & 4,95 & 2,93 & 4,08 \\
SK $(\%)$ & 5,79 & 7,70 & 4,32 & 5,53 \\
\hline
\end{tabular}

\section{Metode Penelitian}

Metode penelitian yang digunakan adalah rancangan acak lengkap (RAL) yang terdiri dari 4 perlakuan dan 5 ulangan. Perlakuannya adalah sebagai berikut:
P0 : Konsentrat (Pakan Kontrol)
$(100 \%)$
P1 : Konsentrat (50\%) + Daun Singkong (50\%)
P2 : Konsentrat $(50 \%)+\operatorname{Kol}(50 \%)$
P3 : Konsentrat (50\%) + Daun Singkong $(25 \%)+$ Kol (25\%) 


\section{Parameter Penelitian}

\section{Mortalitas Induk}

Mortalitas total merupakan persentase jangkrik yang mati dari total jangkrik selama penelitian yaitu membagi jangkrik yang mati selama penelitian dengan jumlah individu pada awal penelitian dikali $100 \%$.

Mortalitas (\%) :

Jumlah jangkrik yang mati $\times 100 \%$

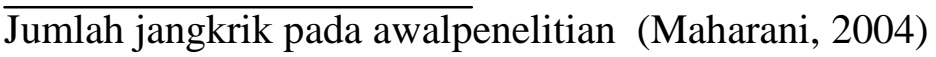

\section{Lama Penetasan (hari)}

Penghitungan lama penetasan dilakukan dengan menghitung waktu yang dibutuhkan telur sejak mulai diinkubasi sampai menetas (Maharani, 2004).

\section{Produksi Telur}

Produksi telur (butir/hari) yang ditentukan dari jumlah telur hasil pemanenan pada setiap perlakuan dibagi dengan banyak jumlah induk betina dalam perlakuan, kemudian dilakukan perhitungan kumulatif sampai akhir produksi (Maharani, 2004).

\section{Daya Tetas Telur (\%)}

Penghitungan daya tetas dilakukan dengan menghitung jumlah telur yang berhasil menetas dari jumlah telur yang diinkubasi. Persentase daya tetas dihitung dengan menggunakan rumus sebagaiberikut :

Dayatetas :

Jumlah telur yang menetas $\times 100 \%$

Jumlah telur yang diinkubasi (Widyaningrum, 2001).

\section{Pelaksanaan Penelitian}

\section{Persiapan Kandang dan Peralatan}

Kandang yang digunakan terdiri dari 20 plot, sebelum jangkrik dimasukkan, kandang dibersihkandan didesinfaktan. Kandang harus dilengkapi dengan tempat pakan. 


\section{Penyusunan Ransum}

Bahan penyusun ransun yang dugunakan terdiri atas tepung jagung, tepung ikan, dedak padi, bungkil kedelai dan daun singkong sebagai hijauan. Bahan peyusun ransum sebaiknya ditimbang terlebih dahulu sesuai komposisi ransum yang telah ditentukan dalam formulasi setiap perlakuan

\section{Pemeliharaan Jangkrik}

Sebelum Jangkrik diberi perlakuan, dilakuakan penimbangan bobot badan. Pemberian pakan secara ad libitum.

\section{Prosedur Penelitian}

Penelitian pada fase reproduksi (masa bertelur) ini merupakan rangkaian penelitian dari fase pertumbuhan dengan perlakuan yang sama. Penelitian dimulai dengan pemindahan jangkrik yang sudah dewasa tubuh (berumur 45 hari) dari kandang pembesaran ke kandang indukan (kandang penelitian). Jangkrik yang dijadikan sample penelitian adalah jantan yang dipilih adalah jangkrik yang sudah mengeluarkan suara mengerik berupakan isyarat bahwa jangkrik tersebut siap untuk membuahi betina, sedangkan jangkrik betina yang siap untuk dibuahi akan mencari sumber suara dan mendekatinya dan jangkrik betina tersebut telah memiliki ovipositor. Jangkrik dipilih dalam keadaan sehat dan lengkap (tidak ada bagian tubuh yang hilang seperti kaki, antena, dan lain-lain) (Sukarno, 1999).

\section{Pengambilan Data}

Pengambilan data dilakukan setelah jangkrik umur 45 hari (siap kawin) yaitu :

1. membagi jangkrik yang mati selama penelitian dengan jumlah individu selama penelitian dikali $100 \%$.

2. Lama penetasan ditentukan atas dasar berapa lama waktu yang dapat dicapai untuk menghasilkan telur atau waktu yang dibutuhkan telur mulai diinkubasi sampai menetas. Telur - telur jangkrik dipanen dengan menyaring media telur dengan air.

3. Produksi telur dihitung dengan cara menimbang telur 100 butir kemudian dibagi dengan berat telur secara keseluruhan dikali 100. Produksi telur (butir/ekor) ditentukan dari jumlah telur hasil pemanenan pada setiap perlakuan dibagi dengan jumlah induk betina dalam perlakuan. 
4. Penghitungan daya tetas dilakukan dengan menghitung jumlah telur yang berhasil menetas dari jumlah telur yang diinkubasi dikali $100 \%$.

\section{Analisis Data}

Analisis data dilakukan dengan menggunakan analisis ragam (Annova), apabila diantaraperlakuan terdapat pengaruh nyata maka akan dilanjutkan dengan dengan menggunakan uji Duncan.

\section{HASIL DAN PEMBAHASAN}

Hasil penelitian diperoleh rekapitulasi data perlakuan terhadap mortalitas induk, lama penetasan, produksi telur dan daya tetas jangkrik kalung(Gryllus bimaculatus) padaTabel 3.

Tabel 3. Rekapitulasi Data daya tetas jangkrik

\begin{tabular}{|c|c|c|c|c|}
\hline Perlakuan & $\begin{array}{c}\text { Mortalitas Induk } \\
(\%)\end{array}$ & $\begin{array}{l}\text { Lama Penetasan } \\
\text { (Hari) }\end{array}$ & $\begin{array}{l}\text { Produksi Telur } \\
\text { (butir/hari) }\end{array}$ & $\begin{array}{c}\text { Daya Tetas } \\
(\%)\end{array}$ \\
\hline P0 & $16,66^{\mathrm{tn}} \pm 5,89$ & $10,20^{\mathrm{C}} \pm 0,47$ & $170,28^{\mathrm{A}} \pm 83,72$ & $42,60^{\mathrm{C}} \pm 12,42$ \\
\hline $\mathrm{P} 1$ & $14,99^{\mathrm{tn}} \pm 6,97$ & $10,80^{\mathrm{C}} \pm 0,47$ & $424,32^{\mathrm{C}} \pm 78,60$ & $34,80^{\mathrm{B}} \pm 14,49$ \\
\hline $\mathrm{P} 2$ & $14,98^{\mathrm{tn}} \pm 6,97$ & $8,20^{\mathrm{A}} \pm 0,44$ & $286,64^{\mathrm{B}} \pm 78,61$ & $21,00^{\mathrm{A}} \pm 7,77$ \\
\hline P3 & $9,99^{\mathrm{tn}} \pm 3,27$ & $9,20^{\mathrm{B}} \pm 0,44$ & $438,24^{\mathrm{D}} \pm 132,48$ & $44,80^{C} \pm 13,51$ \\
\hline & $\begin{array}{l}\text { member } \\
\text { tn }=\text { tida }\end{array}$ & ten & $\begin{array}{l}\text { ang sama menunju } \\
\text { at nyata }(\mathrm{P}<0,01)\end{array}$ & in perlakuan \\
\hline
\end{tabular}

\section{Mortalitas Induk}

Mortalitas induk merupakan persentase jangkrik yang mati dari total jangkrik yang mati selama penelitian yaitu membagi jangkrik yang mati selama penelitian dengan jumlah individu selama penelitian dikali $100 \%$. Rataan mortalitas induk selama penelitian dapat dilihat pada Tabel 3 .

Tabel 3menunjukkan bahwa hasil rataan mortalitas induk jangkrik kalung tertinggi pada perlakuan P0 (konsentrat) yaitu sebesar 16,66\%, sedangkan mortalitas induk jangkrik kalung terendah terdapat pada perlakuan P3 (konsentrat + kol) yaitu sebesar 9,99\%.

Hasil analisis ragam pada penelitian ini menunjukkan bahwa perlakuan memberikan pengaruh tidak nyata terhadap mortalitas induk, hal ini diduga karena kondisi lingkungan penetasan meliputi media yang digunakan dalam penelitian yaitu suhu, kelembaban serta kondisi ruangan yang sesuai hal ini sesuai pernyataan Paimin et al.(1999) menyatakan bahwa 
jangkrik cenderung bersifat kanibal pada masa-masa produktif meskipun tersedia pakan yang cukup, sifat kanibalisme jangkrik sekitar 50 - 60\%. Aryani (2002) menyatakan bahwa jangkrik kalung berperilaku sangat agresif dan cenderung suka berkelahi sehingga tingkat mortalitasnya tinggi.

Penelitian Maharani (2004) menunjukkan rataan mortalitas induk yaitu 35,04\%, lebih rendah dari penelitian ini yaitu 56,64\%. Hal ini disebabkan karena pengaruh sifat jangkrik kalung berprilaku agresif dan suka berkelahi (Tim PPPI, 1999).

\section{Lama Penetasan}

Lama penetasan ditentukan atas dasar berapa lama waktu yang dapat dicapai untuk menghasilkan telur atau waktu yang dibutuhkan telur mulai diinkubasi sampai menetas. Telur - telur jangkrik dipanen dengan menyaring media telur dengan air. Berikut merupakan rataan lama penetasan jangkrik kalung.

Tabel 3 menunjukkan bahwa hasil rataan lama penetasan jangkrik kalung tertinggi pada P1 (konsentrat + daun singkong) yaitu sebesar 10,80 hari, sedangkan rataan lama penetasan jangkrik kalung terendah terdapat pada perlakuan P2 (konsentrat + kol) yaitu sebesar 8,20 hari.

Hasil analisis ragam menunjukkan bahwa kombinasi pakan selama penelitian menunjukkan pengaruh sangat nyata $(\mathrm{P}<0,01)$ terhadap lama penetasan jangkrik kalung, sehingga di uji lanjut dengan uji lanjut Duncan yaitu perlakuan P0tidak berbeda nyata dengan P1, tetapi P0 berbeda nyata dengan P2 dan P3 begitu juga dengan P1. Pada penelitian ini diperoleh rataan waktu yang dibutuhkan jangkrik kalung untuk menetas yaitu berkisar antara 8 - 11 hari.

Menurut Paimin et al. (1999) telur jangkrik lokal dialam akan menetas dalam waktu 13 - 14 hari, sedangkan pada spesies Gryllus bimaculatus telur akan menetas pada hari ke 10-12 (Tamioka et al., 1991).

Hasil penelitian diperoleh bahwa rataan waktu yang dibutuhkan untuk menetas lebih cepat yaitu 8 - 10 hari dari pada penelitian Maharani (2004) yaitu 13 - 14 hari. Hal ini diduga karena keseragaman lingkungan penetasan yang meliputi media yang digunakan, suhu dan kelembabab serta media ruang penelitian. Menurut Panut (2003), waktu tetas tidak dipengaruhi oleh jenis pakan. 
Telur - telur jangkrik tidak menetas secara bersamaan, menurut Sridadi dan rachmanto (1999), keragaman lama penetasan ini dikarenakan peletakan telur oleh induk dilakukan secara bertahap.

\section{Produksi Telur}

Produksi telur (butir/hari) ditentukan dari jumlah telur hasil pemanenan pada setiap perlakuan dibagi dengan jumlah induk betina dalam perlakuan. Produksi telur dihitung dengan cara menimbang telur 100 butir kemudian dibagi dengan berat telur secara keseluruhan dikali 100. Adapun rataan produksi telur jangkrik kalung dapat dilihat pada Tabel 3.

Tabel 3menunjukkan bahwa hasil rataan produksi telur jangkrik kalung tertinggi pada perlakuan P3 (konsentrat + daun singkong + kol) yaitu sebesar 438,24 butir/hari, sedangkan rataan produksi telur terendah terdapat pada P0 (konsentrat) yaitu sebesar 170,28 butir/hari.

Hasil analisis ragam menunjukkan bahwa kombinasi pakan selama penelitian menunjukkan pengaruh sangat nyata $(\mathrm{P}<0,01)$ terhadap produksi telur, sehingga di uji lanjut menggunakan ujilanjut Duncan yaitu perlakuan P0 berbeda sangat nyata dengansemua perlakuan, begitu juga dengan P1, P2 dan P3. Hal ini diduga karena protein pada daun singkong lebih tinggi (Tabel 1) dari pada kol yang lebih banyak mengandung banyak air, sehingga kombinasi dari kedua bahan ini menjadi lebih baik karena memenuhi kandungan nutrisi tersebut, keadaan ini mengindikasikan bahwa jangkrik yang sedang berproduksi membutuhkan protein lebih banyak untuk meningkatkan produksi telur jangkrik tersebut.

Produksi telur yang tinggi dapat disebabkan oleh faktor genetik (jenis jangkrik) dan lingkungan. Faktor lingkungan disini adalah tempat asal jangkrik diperoleh dan kombinasi pakan yang diberikan (daun singkong dan konsentrat). Keragaman genetik pada penampilan reproduksi jangkrik juga terlihat pada pencapaian waktu dewasa dan bertelur pertama.Pada penelitian Widiyaningrum (2001) menghasilkan umur pencapaian dewasa yang beragam yaitu berkisar antara umur 48-60 hari.

Penelitian ini rataan produksi telur yaitu 329,87 (butir/hari) lebih tinggi dibanding pada penelitian Maharani (2004) yaitu 203 (butir/hari) hal ini menunjukkan karena kandungan protein sebesar $21 \%$ yang terdapat pada pakan sudah mencukupi untuk meningkatkan produksi telur jangkrik. Hal ini sesuai dengan penelitian Lumowo (2001) menyatakan jangkrik yang diberi pakan buatan $20 \%-22 \%$ lebih baik produksi. 


\section{Daya Tetas}

Penghitungan daya tetas dilakukan dengan menghitung jumlah telur yang berhasil menetas dari jumlah telur yang diinkubasi, dengan cara menghitung telur yang menetas dibagi dengan jumlah telur yang diinkubasi dikali 100\%.

Tabel 3 menunjukkan bahwa hasil rataan daya tetas jangkrik kalung tertinggi pada perlakuan P3 (konsentrat + daun singkong + kol) yaitu sebesar 44,8\%, sedangkan rataan daya tetas jangkrik kalung terendah terdapat pada perlakuan P2 (konsentrat + kol) yaitu sebesar $21 \%$.

Hasil analisis ragam menunjukkan bahwa jenis kombinasi pakan berpengaruh nyata $(\mathrm{P}<0,05)$ terhadap daya tetas telur jangkrik kalung, kemudian di uji lanjut menggunakan uji lanjut Duncan yaitu perlakuan P0 berbeda sangat nyatadenganperlakuan P1 dan P2, dan P0 tidak berbeda nyata dengan P3.Hal ini sesuai dengan peneltian Widianingrum (2001) bahwa sex ratio $5: 1$ lebih tinggi daya tetas hal ini disebabkan memungkinkan pejantan untuk membuahi telur. Jangkrik memiliki kemampuan bertelur tanpa dibuahi pejantan namun telur - telur yang dihasilkan tidak fertil.

Pada penelitian ini rataan daya tetas $35,8 \%$ lebih rendah dari pada penelitian Maharani (2004) yaitu 60,23\%, disebabkan kesulitan mengontrol media tetas pasir karena pada media pasir kelembaban sangat berfluktuasi dikarenakan pada media ini kurang mampu menahan air sehingga media sangat cepat kering Sukarno (1999).

\section{KESIMPULAN}

Kesimpulan dari penelitian ini menunjukkan bahwa pemberian konsentrat dengan daun singkong (Manihot utilissima) dan kol (Brassica oleraceae L) dapat meningkatkan daya tetas, produksi telur dan mempercepat waktu penetasan terhadap jangkrik kalung (Gryllus bimaculatus).

\section{DAFTAR PUSTAKA}

Aryani, R. 2002. Pengaruh tipe kandang bersekat terhadap pertumbuhan jangkrik kalung(Gryllu sbimaculatus). Skripsi. Fakultas Peternakan. Institut Pertanian Bogor, Bogor.

Lumowo, A. T. 2001. Pertumbuhan Tiga Jenis Jangkrik Lokal (Kalung, Cliring dan Cendawan) dengan Pakan yang berbeda. Skripsi. Fakultas Peternakan. Institut Pertanian Bogor. Bogor. 
Maharani, S.E. 2004.Performa Reproduksi Jangkrik Cliring (Gryllus miratus) yang mendapatkan konsentrat dan Daun singkong (Manihot esculenta) atau Daun Pepaya (Carica papaya). Institut Pertanian Bogor. Bogor.

Paimin, F. B., 1999. Mengatasi Permasalahan Beternak Jangkrik. Penebar Swadaya, Jakarta.

Panut,I 2003. Pengaruh pemberian pakan konsentrat dengan daun kangkung dan daun singkong terhadap produktivitas jangkrik kalung umur 60 - 90 hari. Skripsi. Fakultas Pertanian IPB. Bogor.

Soenanto, H., 1999. Kiat Sukses Beternak jangkrik. Aneka Ilmu. Semarang.

Sridadi dan Rachmanto, 1999. Teknik Beternak Jangkrik, cara mudah dan menguntungkan. Kanisius, Yogyakarta.

Sukarno,H.1999. Budidaya Jangkrik. Cetakan I. Kanisius. Yogyakarta.

TIM Penulis Pustaka Pelangi Indonesia. 1999. Jangkrik. Pustaka Pelangi Indonesia, Surabaya.

Tomioka, K,T.Wakatsuki, K. Shimono and Y. Chiba. 1991. Circadian Control of hetching in the cricket, Gryllus bimaculatus, J. Insect Physiol. 37(5) : 365-371.

Widyaningrum,P. 2001. Pengaruh Padat Penebaran dan Jenis Pakan terhadap Produktivitas Tiga Spesies Jangkrik ideal yang dibudidayakan. Disertasi Program Pasca Sarjana. Institut Pertanian Bogor, Bogor. 